\title{
Asset-rich and cash-poor: which older adults value reverse mortgages?
}

\author{
Joelle H. Fong ${ }^{1 \star}$ (D), Olivia S. Mitchell ${ }^{2}$ and Benedict S. K. Koh ${ }^{3}$ \\ ${ }^{1}$ Lee Kuan Yew School of Public Policy, National University of Singapore, Singapore, ${ }^{2}$ The Wharton School, \\ University of Pennsylvania, Philadelphia, Pennsylvania, USA and ${ }^{3}$ Lee Kong Chian School of Business, \\ Singapore Management University, Singapore \\ ${ }^{*}$ Corresponding author. Email: j.fong@nus.edu.sg
}

(Accepted 8 June 2021; first published online 2 August 2021)

\begin{abstract}
Home equity represents a substantial share of retirement wealth for many older persons, particularly in Asia where national housing policies have encouraged home-ownership. This paper explored the potential for reverse mortgages to help 'asset-rich and cashpoor' older Singaporeans unlock their home equity while ageing in place. The empirical analysis was based on a nationally representative survey of home-owners age $50+$ in the 2018 Singapore Life Panel $(\mathrm{N}=6,258)$. Our analyses showed that the average older home-owner holds some 60 per cent of total net wealth in housing equity, suggestive of high demand potential for reverse mortgage products. Nevertheless, actual interest in such products was much below potential demand. Only one in four older home-owners indicated interest in commercial reverse mortgages if these were to become available; a larger majority had never heard of the financial product. Interest in reverse mortgages was positively associated with product awareness and self-rated product understanding. This implies that a critical step towards building consumer interest would be to enhance awareness of such products and simplify related contract terms. Having a mortgage, fewer children, financial literacy and preparedness for retirement were also positively associated with interest level. These results have implications for targeted interventions to enhance consumer awareness and spur interest in reverse mortgages, especially in ageing societies where older people have built up substantial equity through the housing market over time.
\end{abstract}

Keywords: home-ownership; housing wealth; financial literacy; retirement policy

\section{Introduction}

In most developed nations, older persons tend to have home equity even if they have few liquid assets. Reverse mortgage programmes enable older home-owners to unlock and consume a portion of their home equity without the need to leave their homes. With a reverse mortgage, the home-owner borrows from a lender using the property as collateral. Borrowers may elect to take the funds as a lump

\footnotetext{
(C) The Author(s), 2021. Published by Cambridge University Press. This is an Open Access article, distributed under the terms of the Creative Commons Attribution licence (http://creativecommons.org/licenses/by/4.0/), which permits unrestricted re-use, distribution, and reproduction in any medium, provided the original work is properly cited.
} 
sum, a line of credit or as structured monthly payments. The loan is then repaid with interest, usually on death, from the sale proceeds of the property. This is particularly important given older adults' strong attachment to their homes, as well as their desire to age in place if they can (Jacobs, 1986). In view of the fact that older home-owners can use the money to supplement retirement consumption, it is surprising that reverse mortgage markets have been slow to develop globally.

Prior studies have documented underdeveloped reverse mortgage markets in Australia, Italy, The Netherlands, Singapore and the United States of America (USA) (Phang, 2015; Fornero et al., 2016; Davidoff et al., 2017; Dillingh et al., 2017; Jefferson et al., 2017). Several reasons have been offered for the product's slow growth, including high transaction costs (Mitchell and Piggott, 2004), precautionary savings needs (Nakajima and Telyukova, 2017) and volatile house prices (Chen and Yang, 2020). Consumer preferences also play a role since some older adults perceive housing equity as a financial buffer against adversity, and so they are reluctant to exploit this asset unless in crisis (Morgan et al., 1996; Leviton, 2002).

The complexity of reverse mortgages also makes them less appealing to financially illiterate consumers. For example, Davidoff et al. (2017) found that older US home-owners have limited understanding of Home Equity Conversion Mortgages contract terms. Some knowledgeable home-owners expressed greater interest in using the product, implying that reverse mortgage take-up rates could be boosted via consumer education and by simplifying product explanations. In the Asian context, Merton and Lai (2016) argued that reverse mortgages could be marketed more effectively and efficiently to both retirees and their beneficiaries. A study of urban Chinese home-owners aged 45-65 found that interest in reverse mortgages was positively associated with product understanding: 89 per cent of the home-owners found reverse mortgages interesting after reading a numerical description of a hypothetical product (Hanewald et al., 2020).

Singapore has one of the highest home-ownership rates among developed economies, with home-ownership at or above 90 per cent since the 1990s (Singapore Department of Statistics, 2019). Yet few older Singaporean households access their home equity, leaving them 'asset-rich but cash-poor' in retirement (McCarthy et al., 2002; Phang, 2018). This reality has prompted some analysts to explore the dynamics of the reverse mortgage market, though most prior work has approached the analysis exclusively from the supply side (Chia and Tsui, 2009; Doling and Ronald, 2012; Phang, 2015, 2018). For example, Phang (2015, 2018) highlighted that the products offered by private lenders were complex and had 'retiree-unfriendly' design features (e.g. eligibility age of 70, 50-year minimum remaining lease on the property, etc.). With such stringent conditions imposed by financial institutions, the pool of housing units available for reverse mortgages is drastically reduced. Here, by contrast, we explore the demand side for reverse mortgages.

Our study sought to examine the demand for reverse mortgages among homeowners age 50+ in Singapore along two dimensions. First, we estimated the potential interest in reverse mortgages by studying the wealth composition of older home-owners. This contextualises how important housing equity is to the average older Singaporean, and it underscores the 'asset-rich and cash-poor' conclusion. 
Second, we drew on a module we designed to gain insights into the actual interest levels in reverse mortgages. We also assessed the factors that independently influence consumers' preferences in reverse mortgages, focusing on the potential effects of poor product understanding and lack of product awareness.

\section{Background}

\section{National housing policy in Singapore}

Singapore is a land-scarce country with a large public housing programme known as the Housing Development Board (HDB). Unlike public housing meant for lower-income households in other countries, HDB housing provides options for a range of socio-economic classes. Over 80 per cent of the total population lives in HDB housing (HDB, 2018), most of which consists of high-rise flats on state-owned land; these are planned, built and allocated by the government. They are located in high-density housing estates which are self-contained satellite towns with schools, supermarkets, clinics, food centres as well as recreational facilities. HDB home-owners are typically granted ownership rights for 99 years under a leasehold system that allows land to be recycled over time (HDB, 2019). Private housing in Singapore accounts for about 20 per cent of the total housing stock and, subject to certain conditions, HDB home-owners may invest in private properties (Phang, 2018). Over the past several decades, both public and private housing prices have experienced significant appreciation (Chia et al., 2017).

Since 1968, households may make pre-retirement withdrawals from their pension accounts to finance home purchases. Public and private home purchases can be financed through the Central Provident Fund (CPF), a mandatory definedcontribution scheme with national coverage. Plan participants contribute as much as 37 per cent of their monthly wages to individual accounts, and part of these savings can be used as a down-payment for a house and to service subsequent mortgage payments subject to certain withdrawal thresholds (Central Provident Fund Board, 2019). The government also provides eligible public housing buyers with subsidies. Home-ownership is believed to have generated positive externalities, public spiritedness, a sense of belonging and 'good social behavior' (Low and Aw, 1997). It also allowed Singaporeans to share in the economic success of the country as property values appreciated. Nevertheless, as Singapore's population ages, a dilemma confronting policy makers is how to help older adults convert their housing assets into retirement income streams.

\section{Reverse mortgage market evolution}

Commercial reverse mortgages in Singapore were first offered by a local insurance co-operative (called NTUC Income) in 1997. The programme targeted private home-owners age 70-90 without property loans. By 2006, NTUC Income had issued around 350 reverse mortgage loans for private properties. In the same year, the government permitted HDB home-owners to take up reverse mortgages, following which NTUC Income extended reverse mortgages to this segment of home-owners. OCBC Bank - one of the big three commercial banks - also entered the market. Nevertheless, only 24 HDB home-owners took up reverse mortgages 
between 2006 and 2009, and thereafter the sale of reverse mortgages was discontinued due to lack of demand. In 2014, NTUC Income was servicing only 38 private properties and ten HDB reverse mortgages (The Straits Times, 2014).

One supply-side explanation offered for the failure of the Singaporean reverse mortgage market pertained to a contract feature which capped the maximum loan at 70 per cent of the property's prevailing value throughout the tenure of the loan. If house prices were to decline, resulting in the loan breaching the cap, the lender would stop paying the borrower and take steps to recover the loan. This tail risk became apparent to the public in 2009, when a couple sued NTUC Income alleging wrongful seizure and sale of their property (The Business Times, 2009). The couple had entered into a reverse mortgage contract in 1997 when their home was valued at over S $\$ 2$ million. By 2004, however, the house value had fallen to $S \$ 1.1$ million, and the borrowers were informed they needed to make cash repayments to bring down the loan to value ratio. By 2006, the borrowers' outstanding balance had grown to over S \$1 million, whereupon NTUC Income repossessed and sold the property for just over $\$ 1$ million. The couple was then asked to pay the alleged shortfall of $S \$ 55,000$. While the case was eventually settled out of court, the negative publicity and the fact that the commercial product permitted recourse to the lender is believed to have contributed to the early demise of the reverse mortgage market in Singapore.

\section{Methods}

\section{Data and sample}

Our data were from the Singapore Life Panel (SLP) ${ }^{\circledR}$, an ongoing high-frequency internet survey administered for a representative cohort of age-eligible Singaporean citizens and permanent residents age 50-70 when first recruited in 2015 by the Singapore Management University. The survey includes many globally harmonised questions on respondents' consumption, health, employment, socioeconomic status, retirement expectations and social networks. After the baseline interview where 15,212 persons were surveyed, monthly response rates have remained at around 70 per cent (Vaithianathan et al., 2018). Monthly interviews track individual and household circumstances longitudinally. Our analysis used data from the 2018 SLP $^{\circledR}$, including a special module on reverse mortgages that we developed. This module assessed older adults' interest and preferences pertaining to reverse mortgages, as well as their levels of product understanding and awareness; a detailed description of the survey is provided below.

Our full study sample comprised 6,814 subjects age $50+$ who responded to the special module on reverse mortgages and who also had complete asset and wealth information. We identified home-owners as persons who responded 'Yes, fully or partly own' to this question: 'Do you [and/or your spouse] own or partly own the house, flat or apartment in which you live?' There were 6,258 (91.8\%) homeowners and $556(8.2 \%)$ non-home-owners, for a home-ownership rate of 91.8 per cent, in line with the aggregate home-ownership rate for Singapore. Because home-ownership is a prerequisite for reverse mortgages, we restricted our working sample to the subset of older home-owners $(\mathrm{N}=6,258)$. 


\section{Wealth measures}

To evaluate the potential demand for reverse mortgages, we computed each household's net housing wealth as a share of total net worth. Net housing wealth was operationalised as the current market value of all residential properties less outstanding mortgage debt (if any), reported by respondents. This included the value of the individual's primary and any secondary residences, and was consistent with prior studies (e.g. Wind and Dewilde, 2018). Four separate wealth components were summed to obtain net non-housing wealth, as follows:

(1) Net financial wealth, including checking/saving balances, investments and insurance holdings, less outstanding debt not related to housing.

(2) Non-financial assets, including business assets, and motor vehicles.

(3) CPF pension wealth.

(4) Non-CPF pension wealth (e.g. personal or employer-provided pension plans).

Household total net worth was the sum of net housing and net non-housing wealth.

\section{Reverse mortgage survey}

Our reverse mortgage questionnaire design drew on recent research by Hanewald et al. (2020) who surveyed urban Chinese on a similar topic. That study explored whether interest in commercial reverse mortgages differed between 1,100 older home-owners and 1,100 adult children, asking the latter whether they would recommend the product to their parents. Of note in that study was the use of a format where respondents were first presented with a description of a hypothetical reverse mortgage. The aim was to address the unfamiliarity that most people have with reverse mortgages, and to avoid any (positive or negative) connection with any existing products already offered in the market, the product was simply named 'product ABC'. Next participants were shown a numerical example illustrating how product $\mathrm{ABC}$ worked. Survey participants then rated their understanding of and interest in product $\mathrm{ABC}$.

We followed a similar format in our questionnaire design (for question wordings, see the online supplementary material). First, we qualitatively described a hypothetical reverse mortgage product named 'product $\mathrm{ABC}$ ' offered by a large local bank in Singapore. Similar to previous products offered in the market, the payouts could be in the form of an upfront lump-sum payment, monthly payments for life or some other arrangement (e.g. for a fixed period of months). We also stated that no taxes would be related to the equity extraction due to the product. Second, we showed how product $\mathrm{ABC}$ worked using the example of a married couple who owned a property worth $S \$ 400,000$ in Singapore. The property price of $S$ $\$ 400,000$ assumed in the example reflects the average home value of public housing in Singapore, and it is fairly close to the median net housing wealth observed among our respondents. We also included relevant information on the interest rate used for valuation, payout structure and different debt repayment scenarios should the home-owners pass away.

Responses to three main questions were collated: 
(1) Hypothetically, would you be interested in such products if they were available in Singapore? (Yes/No).

(2) Have you ever heard of such a product? (Yes/No).

(3) How do you rate your understanding of product $\mathrm{ABC}$ ? $(5=$ completely clear, $4=$ mostly clear, $3=$ generally clear, $2=$ mostly confusing, $1=$ completely confusing).

Question (1) sought to measure the older home-owners' interest in reverse mortgages. Responses to this question were binary and used as the outcome variable in our regression models. Questions (2) and (3) measured product awareness and understanding, respectively, and were used as explanatory variables in our regressions. On the basis of previous studies revealing consumer difficulties in understanding financial products generating retirement income, it was anticipated that product awareness and understanding would be low, possibly dampening interest in reverse mortgages. Follow-up questions were also asked based on responses to Question (1). If respondents answered 'Yes', we asked them to indicate how they would use the funds. If respondents answered 'No', we asked them to indicate why.

\section{Statistical analysis and covariates}

We implemented two probit regression models to evaluate factors that could independently influence consumer interest in reverse mortgages. Aside from product awareness and product understanding, Model 1 included a standard set of sociodemographic factors and factors pertinent to financial decision-making: sex, marital status, age groups, education, currently working, income, net non-housing wealth, financial literacy, manage household finance, financially prepared in retirement, financial risk tolerance and financial planning horizon. Respondent age groups were 50-54, 55-59, 60-64, 65-69 and 70+, while categories for education were: less than secondary, secondary and post-secondary. Self-rated product understanding (range 1-5) and financial literacy score (range 0-3) were coded as continuous variables. The latter is based on the 'Big Three' financial literacy questions testing key concepts on numeracy, inflation and risk diversification used to measure financial knowledge in over 20 countries (Lusardi and Mitchell, 2008, 2011). Annual income and net non-housing wealth were represented in logs. Separate indicator variables were constructed for all remaining variables.

Model 2 added controls for property type (value of the primary residence in logs; have mortgage; rented out residence; have secondary property), health (fair/poor selfrated health; ever have a chronic condition; likely to live past age 75) and family networks (number of living children; bequest to children/family). We sought to determine whether a fuller specification improves model fit, and whether the relationship between interest in reverse mortgages and product awareness/understanding changed in the presence of additional confounding factors. The binary variable for 'likely to live past age 75 ' is set to 1 for persons age $75+$ (less than $1.5 \%$ ). For persons below age 75, we used responses to the question 'What is the percent chance that you will live to be 75 or more?', where the binary variable is coded 1 if the respondent stated a percentage greater than 50, 0 otherwise. All statistical analyses were carried out using Stata version 16.0 (StataCorp, College Station, TX, USA). 


\section{Results}

\section{Sample characteristics of older home-owners}

Table 1 reports descriptive statistics of the sampled older home-owners, whose average age was 61.9 and just over half (51\%) were female. About 83 per cent were married and 39 per cent had post-secondary education ( $>10$ years of schooling). The mean financial literacy index score was 2.1 with a standard deviation of 0.9 , implying that older Singaporeans averaged two of three correct answers to the 'Big Three' questions fielded. Some 85 per cent reported that they managed their household's finances, 15 per cent had high financial risk tolerance and 42 per cent had a long-term financial horizon. About 44 per cent said they were financially prepared for retirement. Three-fifths of the older adults were currently working, and about 20 per cent were fully retired. Annual income averaged $S \$ 58,487$ (US \$40,940; exchange rate S $\$ 1=$ US $\$ 0.70$ ) and mean net non-housing wealth was S $\$ 529,000$ (US $\$ 370,300$ ). Although 63 per cent stated that they ever had a chronic condition, only about one-third (37\%) rated their health as fair or poor. Subjects had two living children on average, and 96 per cent stated they intended to leave a bequest to their family members.

The net mean value of primary residences held was approximately $S \$ 699,000$ (with a median of $S \$ 450,000$ ). Since respondents were past their fifties, their homes were mostly paid off: the mean mortgage value was S $\$ 29,000$, and only 18 per cent still held a mortgage on their primary residence. Some 8.6 per cent of the sample reported owning one or more secondary properties, and in this subset, the net value of the secondary property (or properties) averaged about $\mathrm{S} \$ 1.26$ million. In the Singaporean context, the higher net value of the secondary property as compared to the primary residence is unsurprising. Many people purchase HDB flats as their first home, and if they can afford it, will later purchase condominiums sold by private developers as a secondary property for investment and rental.

\section{Share of housing wealth among older households}

The importance of housing equity as a share of total net worth among the older home-owners is shown in Table 2. For an average (or mean) household, housing wealth (inclusive of primary and secondary residences) accounted for about 60 per cent of net worth in 2018. Based on our estimates, even if the value of secondary residence(s) was excluded, housing wealth still accounted for a substantial share (52\%) of total net worth for a typical home-owner. This is partly because less than 10 per cent of our sample reported owning secondary properties. In comparison to housing wealth, the other components constituted a much smaller proportion of total net worth. On average, an older home-owner held only 15 per cent of wealth in financial assets, 3 per cent in non-financial assets, 21 per cent in CPF pension savings and 2 per cent in non-CPF pension savings in 2018. Wealth composition was broadly similar for the mean and the median household.

This distributional analysis confirms that older Singaporean home-owners are indeed 'asset-rich and cash-poor'. Although total net worth for our home-owners age $50+$ averaged $S \$ 1,307,000$, some three-fifths of this wealth was locked up in housing, most of it in owner-occupied homes. The bottom section of Table 2 provides 
Table 1. Descriptive statistics of older Singaporean home-owners

\begin{tabular}{|c|c|c|c|}
\hline Variable & Mean & SD & $\%$ \\
\hline \multicolumn{4}{|l|}{ Home-ownership characteristics: } \\
\hline Value of primary residence ( $\mathrm{S} \$$ (thousands)) & 699 & 843 & \\
\hline Mortgage on primary residence (S \$ (thousands)) & 29 & 120 & \\
\hline Have mortgage on primary residence & & & 18 \\
\hline Ever rented out primary residence & & & 8.9 \\
\hline Have secondary property & & & 8.6 \\
\hline Net value of secondary property (S $\$$ (thousands)), of those owning & 1,264 & 1,492 & \\
\hline \multicolumn{4}{|l|}{ Other demographic characteristics: } \\
\hline Female & & & 51 \\
\hline Married & & & 83 \\
\hline Current age & 61.9 & 5.8 & \\
\hline \multicolumn{4}{|l|}{ Age bands: } \\
\hline $50-54$ & & & 8 \\
\hline $55-59$ & & & 32 \\
\hline $60-64$ & & & 28 \\
\hline $65-69$ & & & 19 \\
\hline $70+$ & & & 13 \\
\hline \multicolumn{4}{|l|}{ Education: } \\
\hline Less than secondary & & & 19 \\
\hline Secondary & & & 42 \\
\hline Post-secondary & & & 39 \\
\hline Currently working & & & 60 \\
\hline Fully retired & & & 20 \\
\hline Financial literacy score $(0-3)$ & 2.1 & 0.9 & \\
\hline Manage household finances & & & 85 \\
\hline High financial risk tolerance & & & 15 \\
\hline Longer-term financial horizon & & & 42 \\
\hline Financially prepared in retirement & & & 44 \\
\hline Annual income (S \$) & 58,487 & 97,266 & \\
\hline Net non-housing wealth (S \$ (thousands)) & 529 & 847 & \\
\hline Fair/poor health & & & 37 \\
\hline Ever have chronic condition & & & 63 \\
\hline Likely to live past age 75 & & & 32 \\
\hline Number of living children & 1.9 & 1.0 & \\
\hline Bequest to children/family & & & 96 \\
\hline
\end{tabular}

Note: Percentages are shown for categorical variables; means and standard deviations (SD) are shown for continuous variables. 


\begin{tabular}{|c|c|c|c|c|c|c|}
\hline & \multirow[b]{2}{*}{ Total net worth } & \multirow[b]{2}{*}{ Net housing wealth } & \multirow[b]{2}{*}{ Net financial wealth } & \multirow[b]{2}{*}{ Non-financial assets } & \multicolumn{2}{|c|}{ Pension wealth } \\
\hline & & & & & CPF & Non-CPF \\
\hline Mean (S \$) & $1,307,842$ & 778,766 & 201,049 & 39,328 & 268,284 & 20,415 \\
\hline As $\%$ of net worth & & 60 & 15 & 3 & 21 & 2 \\
\hline Median $10 \%(\mathrm{~S} \$)^{1}$ & 735,025 & 453,299 & 69,238 & 9,243 & 197,759 & 5,486 \\
\hline As $\%$ of net worth & & 62 & 9 & 1 & 27 & 1 \\
\hline \multicolumn{7}{|l|}{ Percentile (S \$): } \\
\hline 10 & 334,000 & 200,000 & 0 & 0 & 14,500 & 0 \\
\hline 30 & 534,175 & 350,000 & 10,000 & 0 & 92,000 & 0 \\
\hline 50 & 769,062 & 450,000 & 50,000 & 0 & 174,486 & 0 \\
\hline 70 & $1,238,500$ & 600,000 & 155,000 & 5,000 & 327,889 & 0 \\
\hline 90 & $2,806,000$ & $1,600,000$ & 545,000 & 70,000 & 641,199 & 52,000 \\
\hline
\end{tabular}

Notes: 1. Refers to subjects falling between the 45th and 55th percentile of the wealth distribution. CPF: Central Provident Fund. 
further insights by ranking respondents based on total net wealth, where we see that even older adults with lower accumulated net worth still held substantial housing assets. For example, persons at the 30th percentile held $S \$ 350,000$ in housing wealth despite having just $S \$ 10,000$ in net financial assets. Those at the 50th percentile of the wealth distribution had about $S \$ 450,000$ in net housing wealth, about nine times what they had in net financial assets (S \$50,000). Individuals at the 70th percentile had about $S \$ 600,000$ in net housing wealth, almost four times their net financial assets.

\section{Product interest, awareness and understanding}

Table 3 summarises participants' responses to the three key questions posed in our reverse mortgage module. Interestingly, only one-quarter $(26 \%)$ of the older homeowners indicated that they were interested in reverse mortgages. The remaining threequarters of the sample were uninterested, even if only hypothetically. As a follow-up question, those interested in reverse mortgages were asked how they would use the borrowed funds, by having them allocate 100 points across seven different (randomised) options (listed in Table 3). A large majority (76\%) of the interested respondents stated that the payments from a reverse mortgage would be used to support themselves if they lived longer than average in retirement. Only one in ten reported that they would use the funds to cover expenses in retirement (presumably for medical expenses or aged care), while 8.7 per cent intended to deploy the funds to support their spouse/partner in old age. A small minority indicated that the funds would be channelled to supporting children and/or grandchildren (2.8\%) or siblings $(0.2 \%)$.

Two additional aspects of interest are product awareness and self-rated product understanding. Fewer than one-quarter (22\%) of older home-owners surveyed had ever heard of reverse mortgages (Table 3). This is somewhat surprising, considering that Singapore boosts an educated populace, e.g. four out of five respondents in our sample had at least 10 years of schooling. Over two-thirds (69\%) stated that they had at least a generally clear understanding of product $\mathrm{ABC}(13 \%$ were completely clear, $13 \%$ mostly clear and $43 \%$ generally clear), while 32 per cent were mostly or completely confused. In other words, a majority of the sample deemed the contract terms of product $\mathrm{ABC}$ as relatively clear. Despite this, however, only one-quarter of the older home-owners indicated interest in reverse mortgages.

Figure 1 provides insight into why some older Singaporean home-owners are uninterested in commercial reverse mortgages. Among respondents who answered 'No' to 'whether interested', a sizeable proportion (19.6\%) stated that they want to have as little debt as possible. Many older persons (19.5\%) also wished to leave their properties to children and family members; additionally, 13.8 per cent stated that they did not need the extra income from housing monetisation; and 13.4 per cent felt that reverse mortgages were too complex. Finally, 7.4 per cent of those uninterested in reverse mortgages emphasised their emotional attachment to their homes and 10.0 per cent said they did not trust the provider (being an unnamed large local bank in Singapore in our example).

\section{Regression results}

Table 4 presents estimated marginal effects from multivariate probit regressions of the probability that a respondent indicated 'interest in' reverse mortgage product 
Table 3. Reverse mortgage interest, awareness and understanding

Product interest:

Would you be interested in such products if they were available in Singapore?:

$\begin{array}{lrc}\text { Yes } & 1,614 & 26 \\ \text { No } & 4,544 & 73 \\ \text { Missing } & 100 & 1.6\end{array}$

For those who answered 'Yes' to the above - What would be the primary use of the funds?:

To support myself if I live longer than average in retirement $1,228 \quad 76$

To have the flexibility to cover any expenses in retirement $167 \quad 10$

To support my children and/or grandchildren

To support my parents

To support my spouse/partner in old age

To support my siblings

Other

Missing

Total

Product awareness:

Have you ever heard of such a product?:

Yes

No

Product understanding:

How do you rate your understanding of product $A B C$ ?:

Completely clear

Mostly clear

Generally clear

$2,674 \quad 43$

Mostly confusing

$1,303 \quad 21$

Completely confusing

ABC. In Model 1, significant associations were identified between the outcome variable and product awareness, product understanding, currently working, financial literacy, financially prepared in retirement, income, as well as respondent age group. Importantly, product awareness and understanding both significantly increased consumers' interest in reverse mortgages. Older home-owners who had heard of reverse mortgages were about 3.2 per cent $(p<0.05)$ more likely to 


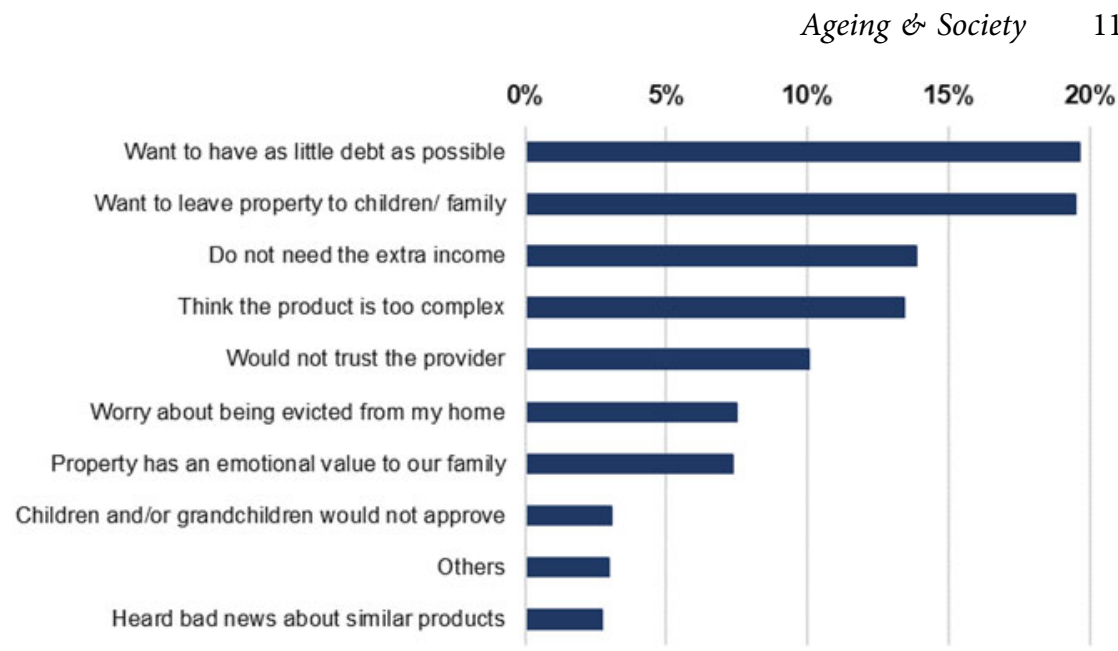

Figure 1. Reasons given for why uninterested in reverse mortgage (analysis of the subset of 4,544 older Singaporean home-owners who responded 'No' to the question 'Would you be interested in such [reverse mortgage] products if they were available in Singapore?').

favour such products, as were those with higher self-rated understanding of product $\mathrm{ABC}$ 's contract terms described in the survey $(11.4 \% ; p<0.01)$. Respondents age 60+ were significantly less interested in reverse mortgages compared to those age 55-59 $(p<0.01)$. As expected, individuals who felt they were financially prepared for retirement, or having higher income, were less likely to be interested in such products compared to their counterparts $(p<0.01)$. Though currently working and financial literacy were positively linked with the outcome, the effects were relatively weak $(p<0.10)$.

The second column of Table 4 provides estimates obtained from an extended model, which had a slightly better fit as indicated by the small reduction of the Bayesian Information Criterion statistic. Overall, the significant effects of product awareness, product understanding, financial literacy, financially prepared in retirement, income and respondent age group remain relatively similar to Model 1 though the effects of currently working became non-significant. We found that certain aspects of property and familial characteristics independently influenced consumers' interest in reverse mortgages. Specifically, home-owners who had not fully paid off their mortgage loans were 4.6 per cent $(p<0.01)$ more likely to find reverse mortgages attractive. Older adults with more living children were significantly less likely to demand such products $(2.4 \% ; p<0.01)$, and those with higher-value homes were also less inclined to take up reverse mortgages $(p<0.10)$.

\section{Discussion}

Reverse mortgages are useful financial instruments that can release housing equity to help finance retirement. Cash-poor but house-rich older home-owners may find such products valuable in helping them liquidate their housing assets while continuing to age in place. The 'puzzle' is why there has been modest uptake of such products in several developed countries including Singapore, where reverse 
Table 4. Factors associated with 'whether interested in' reverse mortgages

\begin{tabular}{|c|c|c|c|c|c|c|}
\hline \multirow{3}{*}{$\begin{array}{l}\text { Variables } \\
\text { Product awareness }\end{array}$} & \multicolumn{3}{|c|}{ Model 1} & \multicolumn{3}{|c|}{ Model 2} \\
\hline & \multicolumn{2}{|c|}{ Marginal effects } & \multirow{2}{*}{$\begin{array}{c}95 \% \mathrm{Cl} \\
0.005,0.059\end{array}$} & \multicolumn{2}{|c|}{ Marginal effects } & \multirow{2}{*}{$\begin{array}{c}95 \% \mathrm{Cl} \\
0.006,0.059\end{array}$} \\
\hline & 0.032 & ** & & 0.032 & ** & \\
\hline Product understanding & 0.114 & $\star \star * *$ & $0.104,0.124$ & 0.114 & 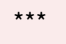 & $0.104,0.125$ \\
\hline Female & -0.009 & & $-0.029,0.108$ & -0.006 & & $-0.026,0.014$ \\
\hline Married & -0.001 & & $-0.031,0.030$ & 0.024 & & $-0.010,0.058$ \\
\hline \multicolumn{7}{|l|}{ Age groups (Ref. 50-54): } \\
\hline $55-59$ & -0.033 & & $-0.072,0.006$ & -0.028 & & $-0.068,0.011$ \\
\hline $60-64$ & -0.066 & *** & $-0.108,-0.025$ & -0.060 & $\star \star \star$ & $-0.102,-0.018$ \\
\hline $65-69$ & -0.071 & 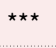 & $-0.117,-0.024$ & -0.058 & $\star \star$ & $-0.106,-0.011$ \\
\hline $70+$ & -0.077 & $\star \star \star *$ & $-0.130,-0.025$ & -0.059 & $\star \star$ & $-0.113,-0.005$ \\
\hline \multicolumn{7}{|l|}{ Education (Ref. Less than secondary): } \\
\hline Secondary & 0.018 & & $-0.014,0.05$ & 0.014 & & $-0.018,0.046$ \\
\hline Post-secondary & 0.006 & & $-0.029,0.041$ & 0.005 & & $-0.03,0.041$ \\
\hline Currently working & 0.026 & * & $-0.004,0.055$ & 0.021 & & $-0.009,0.05$ \\
\hline Fully retired & -0.010 & & $-0.048,0.028$ & -0.009 & & $-0.047,0.029$ \\
\hline Financial literacy score & 0.013 & * & $-0.001,0.027$ & 0.013 & * & $-0.001,0.027$ \\
\hline Manage household finances & -0.008 & & $-0.038,0.022$ & -0.009 & & $-0.038,0.021$ \\
\hline High financial risk tolerance & 0.023 & & $-0.007,0.054$ & 0.022 & & $-0.008,0.052$ \\
\hline Financially prepared in retirement & -0.049 & $\star \star \star *$ & $-0.072,-0.026$ & -0.043 & $\star \star \star *$ & $-0.067,-0.02$ \\
\hline Longer-term financial horizon & -0.020 & & $-0.044,0.004$ & -0.018 & & $-0.043,0.006$ \\
\hline
\end{tabular}




\begin{tabular}{|c|c|c|c|c|c|c|}
\hline Ln annual income & 0.009 & $\star * \star *$ & $0.004,0.013$ & 0.009 & $* \star \star$ & $0.005,0.013$ \\
\hline Ln net non-housing wealth & -0.004 & & $-0.009,0.001$ & -0.003 & & $-0.008,0.003$ \\
\hline \multicolumn{7}{|l|}{ Additional controls: } \\
\hline Ln value of primary residence & & & & -0.015 & * & $-0.03,0.001$ \\
\hline Have mortgage & & & & 0.046 & $\star \star \star *$ & $0.017,0.076$ \\
\hline Ever rented out primary residence & & & & 0.014 & & $-0.027,0.055$ \\
\hline Have secondary property & & & & -0.030 & & $-0.076,0.015$ \\
\hline Fair/poor health & & & & 0.004 & & $-0.021,0.288$ \\
\hline Ever have chronic condition & & & & 0.016 & & $-0.007,0.039$ \\
\hline Likely to live past age 75 & & & & 0.013 & & $-0.011,0.037$ \\
\hline Number of living children & & & & -0.024 & 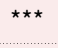 & $-0.039,-0.01$ \\
\hline Bequest to children/family & & & & 0.039 & & $-0.022,0.101$ \\
\hline \multicolumn{7}{|l|}{ Model fit: } \\
\hline Bayesian Information Criterion & 6,151 & & & 6,150 & & \\
\hline
\end{tabular}

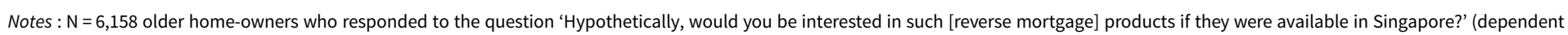

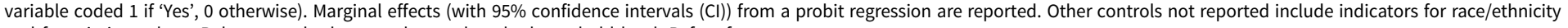
and for missing values. Robust standard errors clustered at the household level. Ref.: reference category.

Significance levels: ${ }^{*} p<0.10,{ }^{* *} p<0.05,{ }^{* *} p<0.01$. 
mortgages were available and aggregate home-ownership rates are high. This article examined the potential and actual demand for reverse mortgages in a nationally representative sample of older home-owners in Singapore, and it also investigated whether the lack of product awareness and poor product understanding negatively influenced consumers' preferences.

Unlike in the USA, where housing assets generally rank after Social Security wealth for older households (Jacobs, 1986; Morgan et al., 1996), housing assets are by far the most important component of personal wealth for the average older Singaporean household. Nevertheless, we found little potential enthusiasm regarding reverse mortgages among older Singaporean home-owners: only one in four indicated interest in reverse mortgages, and the funds that could be released via housing monetisation would be used for old-age support. The remaining threequarters of the sample were not interested, even hypothetically. Our results are striking given that older people hold a majority of their assets - 60 per cent on average - in housing equity, and they underscore Phang's $(2018$, p. 10) view that there is a need for instruments to help Singaporean households 'monetise their housing wealth in the face of retirement and problems related to ageing'.

We also show that greater product awareness and product understanding boost older home-owners' interest levels in reverse mortgages. Older home-owners who had previously heard of reverse mortgages were significantly more interested in such products, as were people who felt they better understood the product's contract terms. These results are robust controlling for property, familial and health characteristics, and they underscore the fact that consumer willingness to take out reverse mortgages will require enhanced consumer awareness and simpler product contract terms. Our results are also in line with those from studies conducted outside Singapore which report that lack of knowledge relates to low interest in reverse mortgages (Merton and Lai, 2016; Davidoff et al., 2017; Hanewald et al., 2020). In Singapore's context, lack of product awareness is particularly problematic. More than three-quarters of older home-owners we surveyed said they had not previously heard of reverse mortgages. This was surprising, considering that such products had been introduced in Singapore in 1997 and were marketed for at least a decade thereafter.

About two-thirds of our sample reported at least a generally clear understanding of product $\mathrm{ABC}$ after the product description and numerical example were presented to them. Since product knowledge is positively and significantly associated with consumer interest, one strategy could be for regulators to work with insurers to market more transparent products with simpler contract terms. For instance, consumer concerns regarding home foreclosure would likely need to be addressed through a 'non-recourse' clause, to protect retirees from owing more than their property is worth. Nevertheless, such a clause may make these products more expensive.

Our analysis was also informative regarding other determinants of demand for reverse mortgages. Older respondents had significantly lower interest in reverse mortgages, as did those with lower income. Notably, older home-owners who were more financially savvy were significantly more interest in reverse mortgages, while those who felt better prepared for retirement were less interested. This is broadly consistent with findings from previous studies suggesting that financial 
literacy enhances household financial decision-making (Lusardi and Mitchell, 2008, 2011). Some related studies (e.g. Fornero et al., 2016; Davidoff et al., 2017) have conversely reported that higher financial literacy is associated with lower interest in reverse mortgages, and they rationalised this result as the financially literate being otherwise better prepared for retirement. In this present study, however, we used a separate measure for financial preparedness, so the effects of financial literacy and preparedness for retirement could be separately identified.

Singaporean home-owners with fewer children were significantly more interested in reverse mortgages (non-significance of the bequest measure possibly because $96 \%$ of the sample stated they wished to leave a bequest). In a similar vein, Hanewald et al. (2020) reported that Chinese home-owners aged 45-69 who did not wish to leave a bequest were significantly more interested in reverse mortgages, indicating that intergenerational aspects are critical in shaping product interest in such markets. Another common factor influencing reverse mortgage demand in both China and Singapore relates to home mortgages. Our results buttress the finding of Hanewald et al. (2020) that having a mortgage is positively associated with an interest in home equity release products, controlling for other factors. While 89 per cent of the older Chinese home-owners expressed interest in reverse mortgages, only 26 per cent did so in our sample. Factors that may account for this difference include an older respondent profile in our sample (mean age of 61.9 versus 52.6 in the Chinese study), as well as the availability of government support schemes for indigent older persons in Singapore (e.g. ComCare Long-Term Assistance Scheme, Silver Support Scheme).

Our analysis must acknowledge a few limitations. First, the analysis is restricted to home-owners age 50+. Younger cohorts of home-owners who are more highly educated and with greater exposure to financial instruments may evaluate reverse mortgages differently from their parents. Second, our study did not consider other possible ways to monetise housing assets, including subletting (renting out a portion of the property to earn rental), downsizing (selling the existing home and buying a smaller house) and a government-supported equity sale scheme where HDB owners can sell the tail-end lease of their 99-year lease flat to the HDB in exchange for cash deposited in their pension accounts. Nonetheless, the HDB equity sale scheme (around since 2009) has also not been popular among older home-owners: fewer than 1 per cent of our sample reported participating in the scheme. Finally, our data are self-reported regarding product interest, awareness and understanding in reverse mortgages. To verify consistency across responses, nonetheless, we performed several cross-checks. For example, we verified that the majority (59\%) of those stating that 'the product is too complex' also found the description of product $\mathrm{ABC}$ to be mostly, or completely, confusing.

Realising the potential of reverse mortgages to finance retirement consumption among older households requires the development of an active market for these instruments. Reverse mortgages are also discussed with increasing frequency by the media and financial advisers, so ageing Singaporeans are increasingly likely to acquire adequate information about the product. Acceptance of reverse mortgages among older home-owners should not be readily assumed, however. Key reasons cited for the disinterest in reverse mortgages in our study included debt aversion, bequest motives and product complexity. Younger cohorts of older home-owners with 
nuclear families and greater exposure to financial instruments may be perhaps more receptive to the notion of housing monetisation than previous cohorts.

Supplementary material. The supplementary material for this article can be found at https://doi.org/10. 1017/S0144686X21001045

Acknowledgement. The authors acknowledge excellent research assistance from Yong Yu.

Financial support. This work was supported by the Singapore Ministry of Education (MOE) Academic Research Fund Tier 3 grant at the Singapore Management University (grant number MOE2013-T3-1-009); the MOE Tier 1 grant at LKY School of Public Policy at the National University of Singapore (grant number MOE2018-T1-R603000296115); and the Pension Research Council/Boettner Center at The Wharton School of the University of Pennsylvania.

\section{References}

Central Provident Fund Board (2019) Public Housing Scheme. Available at https://www.cpf.gov.sg/ Members/Schemes/schemes/housing/public-housing-scheme.

Chen KS and Yang JJ (2020) Housing price dynamics, mortgage credit and reverse mortgage demand: theory and empirical evidence. Real Estate Economics 48, 599-632.

Chia NC and Tsui A (2009) Monetizing housing equity to generate retirement incomes. Singapore Center for Applied Policy and Economics, NUS Economics, Singapore, SCAPE Working Paper 2009/01.

Chia WM, Li M and Tang Y (2017) Public and private housing markets dynamics in Singapore: the role of fundamentals. Journal of Housing Economics 36, 44-61.

Davidoff T, Gerhard P and Post T (2017) Reverse mortgages: what homeowners (don't) know and how it matters. Journal of Economic Behavior and Organization 133, 151-171.

Dillingh R, Prast H, Rossi M and Brancati CU (2017) Who wants to have their home and eat it too? Interest in reverse mortgages in the Netherlands. Journal of Housing Economics 38, 25-37.

Doling J and Ronald R (2012) Meeting the income needs of older people in East Asia: using housing equity. Ageing \& Society 32, 471-490.

Fornero E, Rossi M and Brancati MCU (2016) Explaining why, right or wrong, (Italian) households do not like reverse mortgages. Journal of Pension Economics and Finance 15, 180-202.

Hanewald K, Bateman H, Fang H and Wu S (2020) Is there a demand for reverse mortgages in China? Evidence from two online surveys. Journal of Economic Behavior and Organization 169, 19-37.

Housing and Development Board (HDB) (2018) HDB: About Us. Available at https://www.hdb.gov.sg/cs/ infoweb/about-us.

Housing and Development Board (HDB) (2019) HDB Flat Buyers Own Their Flats. Available at https:// www.hdb.gov.sg/cs/infoweb/hdbspeaks/hdb-flat-buyers-own-their-flats.

Jacobs B (1986) The national potential of home equity conversion. The Gerontologist 26, 496-504.

Jefferson T, Austen S, Ong R, Haffner ME and Wood GA (2017) Housing equity withdrawal: perceptions of obstacles among older Australian home owners and associated service providers. Journal of Social Policy 46, 623-642.

Leviton R (2002) Reverse mortgage decision-making. Journal of Aging and Social Policy 13, 1-16.

Low L and Aw TC (1997) Housing a Healthy, Educated, and Wealthy Nation Through the CPF. Singapore: Times Academic Press.

Lusardi A and Mitchell OS (2008) Planning and financial literacy: how do women fare? American Economic Review 98, 413-417.

Lusardi A and Mitchell OS (2011) Financial literacy around the world: an overview. Journal of Pension Economics and Finance 10, 497-508.

McCarthy D, Mitchell OS and Piggott J (2002) Asset rich and cash poor: retirement provision and housing policy in Singapore. Journal of Pension Economics and Finance 1, 197-222.

Merton R and Lai RN (2016) On an efficient design of reverse mortgages: a possible solution for aging Asian populations. SSRN Working Paper. Available at https://ssrn.com/abstract=3075087.

Mitchell OS and Piggott J (2004) Unlocking housing equity in Japan. Journal of the Japanese and International Economies 18, 466-505. 
Morgan BA, Megbolugbe IF and Rasmussen DW (1996) Reverse mortgages and the economic status of elderly women. The Gerontologist 36, 400-405.

Nakajima M and Telyukova IA (2017) Reverse mortgage loans: a quantitative analysis. Journal of Finance 72, 911-950.

Phang SY (2015) Monetizing housing for retirement in Singapore. School of Economics, Singapore Management University, Working Paper. Available at http://ink.library.smu.edu.sg/soe_research/2128.

Phang SY (2018) Policy Innovations for Affordable Housing in Singapore: From Colony to Global City. Basingstoke, UK: Palgrave Macmillan.

Singapore Department of Statistics (2019) Households: Latest Data. Available at https://www.singstat.gov. sg/find-data/search-by-theme/households/households/latest-data.

The Business Times (2009) Couple sue NTUC Income over reverse mortgage deal gone sour. The Business Times, July 28. Available at https://www.asiaone.com/News/The\%2BBusiness\%2BTimes/Story/A1Story20090728157644.html.

The Straits Times (2014) Reverse mortgages in the spotlight, offer option to ease cash woes. The Straits Times, September 17. Available at https://www.straitstimes.com/business/reverse-mortgages-in-the-spotlightoffer-option-to-ease-cash-woes.

Vaithianathan R, Hool B, Hurd MD and Rohwedder S (2018) High-frequency internet survey of a probability sample of older Singaporeans: the Singapore Life Panel'. The Singapore Economic Review 2018, 1-20. DOI: $10.1142 / S 0217590818420043$.

Wind B and Dewilde C (2018) Home-ownership and housing wealth of elderly divorcees in ten European countries. Ageing \& Society 38, 267-295.

Cite this article: Fong JH, Mitchell OS, Koh BSK (2023). Asset-rich and cash-poor: which older adults value reverse mortgages? Ageing \& Society 43, 1104-1121. https://doi.org/10.1017/S0144686X21001045 